\title{
Toxicology evaluation of selenium protein powder
}

\author{
Shunyi Qin ${ }^{1}$, Lina Liu¹, Jingshen Wang², Fanghong Zhao ${ }^{1}$ and Jifei $\mathrm{Ma}^{1 \text {,a }}$ \\ ${ }^{1}$ College of Animal Science and Veterinary Medicine, Tianjin Agricultural University, Tianjin 300384, China \\ ${ }^{2}$ Tianjin Selenium Egg Biological Technology Co., Ltd., Tianjin 300100, China
}

\begin{abstract}
The experiment was conducted to evaluate the safety of selenium protein powder, a novel organic selenium nutritional supplement, and reported corresponding data and results based on a series of toxicological tests. It was examined to evaluate oral acute toxicity by median lethal dose test and mutagenic potential by bone marrow cell micronucleus test and sperm abnormality test using Kun-Ming mice. The results showed that the oral $\mathrm{LD}_{50}$ of selenium protein powder exceeded $31.25 \mathrm{~g} / \mathrm{kg}$ body weight in mice. No mutagenicity was found by mouse bone marrow cell micronucleus test and mouse sperm abnormality test. The results suggested greater safety of selenium protein powder as a nutritional selenium supplement, and selenium protein powder has the potential for development and application in food systems or functional foods.
\end{abstract}

\section{Introduction}

As an essential trace element for human and animal, selenium is actively involved in the antioxidant defense systems [1], immune function [2], thyroid function and reproduction [3]. The bioavailability of Selenium varies by sources. It is generally accepted that the organic Selenium sources are more bioavailable than the inorganic Selenium sources[4]. Recently, a novel organic selenium nutritional supplement, selenium protein powder is attracting increasing attention due to its high bioavailability and nutrition[5]. Although safety evaluation of different types of selenium compounds had been widely studied [6-8], there was no available data about the safety evaluation of selenium protein powder in the literatures. Therefore, this paper evaluated oral acute toxicity and mutagenicity of selenium protein powder by median lethal dose $\left(\mathrm{LD}_{50}\right)$ test, bone marrow cell micronucleus test and sperm abnormality test.

\section{Materials and methods}

\subsection{Selenium protein powder samples}

Selenium protein powder (Tianjin Selenium Egg Biological Technology Co., Ltd) was made from selenium-enriched eggs. Briefly, hens were fed a diet supplemented with selenized yeast (Alltech Inc., Nicholasville, KY) so that the selenium-enriched eggs were obtained, and then, selenium protein

\footnotetext{
${ }^{\mathrm{a}}$ Corresponding author: hbmjfts@126.com
} 
powder were obtained from selenium-enriched eggs by means of low temperature baking. The total Selenium concentrations in selenium protein powder determined by hydride generation-atomic fluorescence spectrometry method was $38.76 \mu \mathrm{g} / \mathrm{g}$.

\subsection{Oral acute toxicity test}

The median lethal dose $\left(\mathrm{LD}_{50}\right)$ test was conducted to assess the acute toxicity of selenium protein powder. The test was performed by the Spearman-Karber method (Finney, 1978). In brief, one hundred Kun-Ming mice, approximately 4 weeks old, were divided into five groups with equal number of both sexes and equal initial body weight. The mice were administered (via gavage) with selenium protein powder suspended in distilled water at the doses of 12.80, 16.00, 20.00, 25.00 or $31.25 \mathrm{~g} / \mathrm{kg}$ body weight, respectively. Following dosing, the mice were observed for one week for mortality, clinical observations and gross necropsy findings.

\subsection{Bone marrow micronucleus test}

Fifty 8-week-old Kun-Ming mice were divided into five groups with equal number of both sexes and equal initial body weight. Distilled water was given by oral gavage as a negative control, and cyclophosphamide $(40 \mathrm{mg} / \mathrm{kg})$ in physiological saline was given by intraperitoneal injection as a positive control. Selenium protein powder (suspended in distilled water) were given by oral gavage for 2 days ( $24 \mathrm{~h}$ between doses) at doses of 580,1150 or $2300 \mathrm{mg} / \mathrm{kg}$ body weight to mice in other three groups, respectively. The mice were anesthetized and sacrificed $6 \mathrm{~h}$ after the last administration. Bone marrow from the sternum was collected, sectioned and stained by routine clinical protocol, and then observed under the microscope. The numbers of polychromatic erythrocytes (PCE) and normochromatic erythrocyte (NCE), the numbers of PCE with micronuclei were record, and then micronucleus rates were calculate and analyzed by U-test of Poisson distribution.

\subsection{Sperm aberration test}

The sperm aberration test was performed by the standard methods [9]. Twenty-five 8-week-old KunMing male mice, with an average body weight of $30 \mathrm{~g}$, were randomly divided into five groups with equal number and equal initial body weight. Distilled water was given by oral gavage as a negative control, and $40 \mathrm{mg} / \mathrm{kg}$ cyclophosphamide in physiological saline was given by intraperitoneal injection as a positive control.Selenium protein powder were suspended in distilled water, and given by oral gavage for 5 days, at doses of 2250,5000 or $10000 \mathrm{mg} / \mathrm{kg}$ body weight to mice in other three groups, respectively. The mice were anesthetized and sacrificed 35 days after the first administration. The bilateral epididymides were excised and placed in physiological saline and minced with ophthalmic scissors. Smears were prepared on clean slides, fixed with methanol and stained with $1 \%$ eosin. The slides were air-dried and coded for subsequent examination. Morphological evaluation for sperm was carried out using a high-magnification microscope. One thousand sperm were observed for each mouse to record the numbers of the aberrated sperm and aberration ratios were analyzed by Chisquare $\left(\chi^{2}\right)$ test .

\section{Results}

\subsection{Oral acute toxicity assay}

The results showed that mice administered selenium protein powder did not develop any clinical signs of toxicity either immediately or during the post-treatment period even at the highest dose of 31.25 $\mathrm{g} / \mathrm{kg}$ body weight. The general conditions of all mice were normal. No mortality occurred either 
immediately or during the one-week observation period (Table 1). Therefore, the oral $\mathrm{LD}_{50}$ for selenium protein powder is considered to be greater than $31.25 \mathrm{~g} / \mathrm{kg}$ for mice.

Table 1. Results of oral median lethal dose test.

\begin{tabular}{|c|c|c|c|}
\hline $\begin{array}{c}\text { Dosages } \\
(\mathrm{g} / \mathrm{kg})\end{array}$ & $\begin{array}{c}\text { Number of } \\
\text { Animals }\end{array}$ & $\begin{array}{c}\text { Number of } \\
\text { Animal death }\end{array}$ & $\begin{array}{c}\text { Mortality } \\
(\%)\end{array}$ \\
\hline 12.80 & 20 & 0 & 0 \\
\hline 16.00 & 20 & 0 & 0 \\
\hline 20.00 & 20 & 0 & 0 \\
\hline 25.00 & 20 & 0 & 0 \\
\hline 31.25 & 20 & 0 & 0 \\
\hline
\end{tabular}

\subsection{Micronucleus test}

The results showed that the incidence of micronucleus ratios for the male animals were within the range of $0.85-1.40 \%$ except for the positive control $(24.00 \%$ ) ( Table 2), and that the incidence of micronucleus ratios for the female animals were within the range of 1.3-1.9\%o except for the positive control $(25.10 \%$ ) (Table 3$)$. The data showed that there were no statistically significant differences between any of the selenium protein powder dosage groups and the negative control group $(P>0.05)$, whereas the positive control group was significantly different $(P<0.05)$ from others. The results also showed that there were no statistically significant differences of PCE/NCE in all groups $(P>0.05)$. The results indicated that within the dose range of $580-2300 \mathrm{mg} / \mathrm{kg}$ body weight, selenium protein powder did not trigger an increase of micronucleus ratios in vivo.

Table 2. Results of micronucleus test of bone marrow PCE cells in male mice

\begin{tabular}{|c|c|c|c|c|}
\hline $\begin{array}{c}\text { Dosages(mg/ } \\
\mathrm{kg})\end{array}$ & Animals & $\begin{array}{c}\text { Number of } \\
\text { PCE }\end{array}$ & MNF(\%) & PCE/NCE \\
\hline Control & 5 & $5 \times 2000$ & $1.40 \pm 0.46$ & $0.88 \pm 0.05$ \\
\hline 580 & 5 & $5 \times 2000$ & $0.80 \pm 0.30$ & $0.93 \pm 0.03$ \\
\hline 1150 & 5 & $5 \times 2000$ & $1.70 \pm 0.44$ & $0.85 \pm 0.06$ \\
\hline 2300 & 5 & $5 \times 2000$ & $1.20 \pm 0.44$ & $0.83 \pm 0.03$ \\
\hline CP $40 \mathrm{mg} / \mathrm{kg}$ & 5 & $5 \times 2000$ & $24.00 \pm 2.30^{*}$ & $0.93 \pm 0.05$ \\
\hline
\end{tabular}


Table 3. Results of micronucleus test of bone marrow PCE cells in female mice

\begin{tabular}{|c|c|c|c|c|}
\hline $\begin{array}{c}\text { Dosages } \\
(\mathrm{mg} / \mathrm{kg})\end{array}$ & Animals & $\begin{array}{c}\text { Number of } \\
\text { PCE }\end{array}$ & MNF(\%) & PCE/NCE \\
\hline Control & 5 & $5 \times 2000$ & $1.30 \pm 0.25$ & $0.83 \pm 0.06$ \\
\hline 580 & 5 & $5 \times 2000$ & $1.50 \pm 0.42$ & $0.88 \pm 0.07$ \\
\hline 1150 & 5 & $5 \times 2000$ & $1.90 \pm 0.33$ & $0.90 \pm 0.07$ \\
\hline 2300 & 5 & $5 \times 2000$ & $1.50 \pm 0.35$ & $0.87 \pm 0.05$ \\
\hline $\mathrm{CP} 40 \mathrm{mg} / \mathrm{kg}$ & 5 & $5 \times 2000$ & $25.10 \pm 1.73^{*}$ & $0.90 \pm 0.07$ \\
\hline
\end{tabular}

$* P<0.05$ compared with control group.

\subsection{Sperm aberration test}

The results showed that the aberration rates for animals given selenium protein powder were within the range of $1.82 \%$ to $2.46 \%$ while that for the positive control was $12.14 \%$ (Table 4 ). The data showed that there was no statistically significant difference $(P>0.05)$ between any of three dosage groups and the negative control group, whereas the positive control group was significantly different $(P<0.01)$ from the negative control group. The results indicated that, within the dose range of 2250$10000 \mathrm{mg} / \mathrm{kg}$ body weight, the selenium protein powder did not have any detectable mutagenic effect on sperm cells in mice.

Table 4. Results of sperm abnormality test of mice

\begin{tabular}{|c|c|c|c|c|}
\hline Dose $(\mathrm{mg} / \mathrm{kg})$ & Animals & $\begin{array}{c}\text { Numbers of } \\
\text { Sperms }\end{array}$ & $\begin{array}{c}\text { Numbers of } \\
\text { Aberrated } \\
\text { sperms }\end{array}$ & $\begin{array}{c}\text { Frequencies } \\
\text { of } \\
\text { abnormality } \\
(\%)\end{array}$ \\
\hline Control & 5 & $5 \times 1000$ & $24.60 \pm 3.56$ & $2.46 \pm 0.36$ \\
\hline 2250 & 5 & $5 \times 1000$ & $18.20 \pm 3.12$ & $1.82 \pm 0.31$ \\
\hline 5000 & 5 & $5 \times 1000$ & $24.20 \pm 6.39$ & $2.42 \pm 0.64$ \\
\hline 10000 & 5 & $5 \times 1000$ & $18.40 \pm 3.17$ & $1.84 \pm 0.32$ \\
\hline $\mathrm{CP} 40$ & 5 & $5 \times 1000$ & $121.40 \pm 8.49$ & $12.14 \pm 0.85^{* *}$ \\
\hline
\end{tabular}

** $P<0.01$ compared with control group. 


\section{Discussion}

Our results showed that the oral $\mathrm{LD}_{50}$ for selenium protein powder is considered to be greater than $31.25 \mathrm{~g} / \mathrm{kg}$ body weight for mice, indicating that selenium protein powder can be considered a nontoxic material on the basis of the criteria of acute toxic classifications by Ministry of Health, China[9]. Our results also indicated that, as organic selenium, selenium protein powder was shown to have a significantly lower acute oral toxicity than sodium selenite in mouse. Based on our results and previous results[10-12] the toxicity order of Selenium compounds in mice determined as: sodium selenate $>$ sodium selenite $>$ elemental nanoSe $>$ nutritional additive Sel-Plex (selenized yeast) $>$ probiotic LactoMicroSe $>$ selenium protein powder.

As a well-known genotoxic assay, the mouse bone marrow micronucleus test has proven suitable for the evaluation of genotoxic and antigenotoxic actions of compounds [13]. And the frequency of micronucleated polychromatic erythrocytes is a reliable measure of both chromosome loss and breakage [14]. In the micronucleus test, our results showed that within the dose range of 580-2300 $\mathrm{mg} / \mathrm{kg}$ body weight, selenium protein powder did not trigger an increase of micronucleus ratios in mce, which indicated that selenium protein powder was not mutagenic to somatic chromosomes in mice.

The sperm aberration test is a method of evaluating genetic injury to male reproductive cells of mammals (including man) in vivo. Our results showed that, within the dose range of 2250-10000 $\mathrm{mg} / \mathrm{kg}$ body weight, the selenium protein powder did not have any detectable mutagenic effect on sperm cells, and suggested that it would not trigger genetic injury to male reproductive cells of mammals in vivo. According to the National Research Council, the recommended dietary allowance of selenium is $55 \mu \mathrm{g} /$ day for adult men and women[15], and the recommended daily oral dose of selenium protein powder is $500-1000 \mathrm{mg} /$ day. In sperm aberration test, the highest dose of selenium protein powder was settled to $10000 \mathrm{mg} / \mathrm{kg}$ because the dose had reached 700 times of the recommended daily oral dose $(1000 \mathrm{mg})$ for a person of $70 \mathrm{~kg}$ body weight.

Base on the results of above studies, we could conclude that selenium protein powder is safe at the dose of daily-recommended consumption and has the potential for development and application in food systems or functional foods.

\section{Conclusions}

The oral $\mathrm{LD}_{50}$ for selenium protein powder exceeded $31.25 \mathrm{~g} / \mathrm{kg}$ body weight in mice. Selenium protein powder were found to be non-mutagenic and non-genotoxic in the micronucleus test and mouse sperm aberration test, and it has greater safety as a nutritional selenium supplement.

\section{Acknowledgements}

This research was supported by Research Program of Application Foundation and Advanced Technology of Tianjin (grant number: 15JCYBJC30600) and One-three-one Program of Innovative Talents Training of Tianjin.

\section{References}

1. B.R. Cardoso, B.R. Roberts, A.I. Bush, D.J. Hare, Metallomics 7, 1213-1228 (2015)

2. W. Baowei, H. Guoqing, W. Qiaoli; Y. Bin, J. Anim. Physiol. Anim. Nutr. 95, 440-448 (2011)

3. M.P. Rayman, Lancet 365, 233-241(2000)

4. M. Kieliszek, S. Blazejak, Nutrition 29, 713-718 (2013)

5. X. Wang, Y. Wang, S. Qin; H. Wang, J. Wang, China Animal Husbandry and Veterinary Medicine 41, 148-152 (2014)

6. R.J. Shamberger, Mutat. Res. 154, 29-48 (1985)

7. J.C. Griffiths, R.A. Matulka, R. Power, Int. J. Toxicol. 25, 477-485 (2006) 
8. F.R. Moore, G.A. Urda, G. Krishna, J. C. Theiss, Mutat. Res. 367, 33-41 (1996)

9. Ministry of Health, PR China, National Standards of PR China, GB15193.1-15193.21.(2003)

10. I. Benko, G. Nagy, B. Tanczos, E. Ungvari, A. Sztrik, P. Eszenyi, J. Prokisch, G. Banfalvi, Environ. Toxicol. Chem. 31, 2812-2820 (2012)

11. J.C. Griffiths, R.A. Matulka, R. Power, Int. J. Toxicol. 25, 465-476 (2006)

12. M. Shakibaie, A.R. Shahverdi, M.A. Faramarzi, G.R. Hassanzadeh, H.R. Rahimi, O. Sabzevari, Pharm. Biol. 51, 58-63 (2013)

13. B.H. Narayan, N. Tatewaki, V.V. Giridharan, H. Nishida, T. Konishi, Food Funct. 1, 174-179 (2010)

14. M.A. Furtado, L.C.F Almeida, R.A. Furtado, W.R. Cunha, D.C. Tavares, Mutat. Res. Genet. Toxicol. Environ. Mutagen. 657, 150-154 (2008)

15. National Research Council. Dietary Reference Intakes, 300-307 (Washington, DC: National Academy Press, 2000) 